\title{
A Corpus-based Study of Verbs Which are Modified by Qualitative Adverb in Indonesian
}

\author{
K Fajrianisa ${ }^{1}$, T Suhardijanto $^{2}, \mathrm{Z} \mathrm{Nuriah}^{3}$ \\ \{1khairani.fajrianisa71@ui.ac.id, ${ }^{2}$ totok.suhardijanto@ui.ac.id, ${ }^{3}$ zahroh.nuriah@ui.ac.id\} \\ 1,2,3 Universitas Indonesia
}

\begin{abstract}
Indonesian qualitative adverb, sangat 'very', tend to be used as parameter to distinguish verbs and adjectives. If a word is modified by sangat and form grammatical phrase, the word is likely an adjective, e.g. sangat cantik 'very beautiful'. Otherwise, the word is a verb if it forms ungrammatical phrase with sangat, e.g. sangat menari 'very dance' which is not accepted in Indonesian language. Qualitative adverb or adverb of degree also is considered as property of adjective to distinguish it with other lexical category. In reality, sangat is found modified verbs as well, not only adjective. Some verbs accept modification with sangat, e.g. sangat mencintai 'very love (lit.)', sangat ingat 'very remember (lit.)', sangat berpengaruh 'very influence (lit.)', and so on. According to this fact, this research aims to investigate which type of verb that can accept modification with qualitative adverb, in this case is sangat 'very'. This study is a corpus-based grammar research which is still rarely applied in Indonesian grammar, especially in verb and adverb study. Corpus Indonesian Web (IndonesianWac) is used to provide various data which qualitative adverb sangat appear with verbs in Indonesian language. Data of this research are all verbs that accept modification with sangat. The verbs then will be categorized according to its verb type. The verb types used in this study is verb type by Chafe and Cook which has been modified by Tampubolon. The results of the concluded that most of verb that accept modification by sangat 'very' is derivative verb. The verbs are state verbs which is divided as state verb, state experiential verb, and state benefactive verb.
\end{abstract}

Keywords: adjective, adverb, corpus, qualitative adverb, verb, verb type

\section{Introduction}

Qualitative adverb in Indonesian language is an adverb which describes level, degree, and quality [1]. This adverb is also well-known as intensive adverb [2], degree word [3]. intensifier or amplifier [4], and quality marker [[5]. Qualitative or degree adverb has two functions, intensives and downtoner [3]. Intensives function to maximize or boost meaning or scale a quality up and, as downtoners, degree adverb functions to scale downwards from an assumed norm. Indonesian language also has qualitative adverb which function as intensives and downtoners as follows.

Intensives: sangat very, paling most, lebih more

Downtoner: kurang less, sedikit slight, agak quite 
Indonesian language tends to use this adverb as parameter to distinguish verbs and adjectives. If the investigated word can be modified by qualitative adverb, the word is an adjective. Otherwise, if the phrase becomes ungrammatical after it is modified by qualitative adverb, the investigated word is a verb. As examples, lari 'run' is a verb because it forms ungrammatical phrase when lari is modified by sangat 'very'. Meanwhile, cantik 'beautiful' is an adjective because it forms grammatical phrase with qualitative adverb as in phrase sangat cantik 'very beautiful'. Gradation or degree expression is often used as distinctive property of adjective [6]. However, it is still a subject of debate between linguists because degree expression is also found with other category, other than adjective [3], [7]. Following examples are degree expressions which are formed by degree adverb and verb in English (1), Japanese (2), and Germany (3) [8].

(1) He loves his mother very much.

(3) Taroo-wa totemo kurusinda

(2) Er liebt Angela sehr. He loves Angela very 'He loves Angela very much'

Some Indonesian verbs can be modified by qualitative adverb as well as in the examples below.

(4) Ia sangat mencintai perang [...] (doc \#498)

[lit.] She/he very love war

'she/he loves war very much'

Previously, this case has been mentioned by Hasan [1], Kridalaksana [5], Sneddon [8], and Sofyan [9] without any details explanation about which kind of verbs that can be modified by qualitative adverb. It is just mentioned the verb is verb of emotion [1], [5], causative verb formed by suffixation with suffix - kan [8], and affixed verb [9]. If we see in corpus data, verbs that can be modified by qualitative adverb are more vary and not limited to verb of emotion, causative verb, or affixed verb. There are some base verbs found modified by sangat, e.g. ingat. It is also found that. mengetahui 'know', diperlukan 'is needed', berkurang 'decrease', menyadari 'realized', and more non-emotion and non-causative verbs can be modified by qualitative adverb. According to this fact, in depth study of verb type that can be modified by qualitative adverb needs to be done. This research aims to investigate verb types that can be modified by qualitative adverb in Indonesian.

\section{Research Method}

This study is a corpus-based grammar research. Corpus-based approach analyzes the patterned use of grammatical features in text instead of using intuition or native judgement which is done by traditional studies. By using large corpora and computer tools, this approach investigates the frequency distribution of various constructions, the association patterns between grammatical structures and other linguistic and non-linguistics factors, and the factors that affect choices between structural variants [10]. This study uses corpus of Indonesian language from Sketch Engine (https://www.sketchengine.eu/), namely Indonesian Web (IndonesianWaC). Indonesian Web (IndonesianWaC) is a large corpus with $109,236,814$ tokens taken from 27,051 internet articles. Internet articles in this corpus vary, ranging from Wikipedia articles, blogs, to online news. Not all qualitative adverbs in Indonesian language is used for this research. Sangat 'very' is used as prototype of qualitative adverb here as this adverb is frequently used by Indonesian people with 152.471 occurrences in corpus. Word 
Sketch feature in Sketch Engine is used to generate collocate which occur with sangat in phrase. In corpus, the investigated word is called as axis and the words occur with them are called as collocate. The investigated word of this research is sangat and verb is the collocate which appears with sangat. As sangat occurs with various categories from adjective, verb, noun, and another adverb, the collocates need to be categorized according to their part of speech. It is found that 347 verbs appear as collocate of sangat and its occurrences are 46.031 . All verbs is analyzed by categorizing them to verb classes. Verb types which are used in this research is modified by [11] from Chafe and Cook verb classification. Chafe and Cook verb classification is chosen to categorize verb for this research because their classification has been used to explore semantics of verbal affixations in Indonesian language. Tampubolon categorizes Chef and Cook verb classification into 12 basic verb types which is distinguished by their required case or argument on its semantics. Semantic case role used to distinguish each type are agent (A), experiencer (E), benefactive (B), object (O), location (L), and object which is required by state verb (Os). According to its semantic case role, the verb types consist of state (Os, Os, Os), state experiential (E, Os), state benefactive (B, Os), state locative (Os, $\mathrm{L})$, process $(\mathrm{O}, \mathrm{O}, \mathrm{O})$, process benefactive $(\mathrm{E}, \mathrm{O})$, process experiential $(\mathrm{B}, \mathrm{O})$, process locative $(\mathrm{O}, \mathrm{L})$, action $(\mathrm{A}, \mathrm{O}, \mathrm{A}, \mathrm{O}, \mathrm{O})$, action experiential $(\mathrm{A}, \mathrm{E}, \mathrm{O})$, action benefactive $(\mathrm{A}, \mathrm{B}, \mathrm{O})$, and action benefactive $(\mathrm{A}, \mathrm{O}, \mathrm{L})$. Codes in the bracket show required case/arguQualitative adverb in Indonesian mostly modifies affixed verbs, such as tergantung 'depends', berharap 'hope', and menginginkan 'want'. There are only thirteen basic verbs found with sangat, i.e. suka 'like', percaya 'believe', paham 'understand', tahu 'know', bisa 'can', butuh 'need', maju 'go forward', masuk 'get in', tampak 'seen', hidup 'alive', ingat 'remember', nampak 'seen', and dapat 'can'. Qualitative adverb in Indonesian mostly modifies affixed verbs, such as tergantung 'depends', berharap 'hope', and menginginkan 'want'. There are only thirteen basic verbs found with sangat, i.e. suka 'like', percaya 'believe', paham 'understand', tahu 'know', bisa 'can', butuh 'need', maju 'go forward', masuk 'get in', tampak 'seen', hidup 'alive', ingat 'remember', nampak 'seen', and dapat 'can'. ment for each verb type.

\section{Results And Discussion}

Qualitative adverb in Indonesian mostly modifies affixed verbs, such as tergantung 'depends', berharap 'hope', and menginginkan 'want'. There are only thirteen basic verbs found with sangat, i.e. suka 'like', percaya 'believe', paham 'understand', tahu 'know', bisa 'can', butuh 'need', maju 'go forward', masuk 'get in', tampak 'seen', hidup 'alive', ingat 'remember', nampak 'seen', and dapat 'can'. Most of verbs which accept modification with qualitative adverb sangat very are derivative verbs. The verbs are derived from the stem under category adjective, adverb, noun, preposition, and numeralia. Deadjectival verb and denominal verb are two derived verbs that are mostly found in data.

\begin{tabular}{rll}
\hline Verb Type & Total & Freq \\
\hline base verbs & 13 & 673 \\
deadjectival verbs & 110 & 10510 \\
deadverbial verbs & 7 & 374 \\
denominal verbs & 118 & 18412 \\
deprepositional verbs & 3 & 369 \\
denumeralial verbs & 1 & 59 \\
deverbal verbs & 102 & 15634 \\
Total & $\mathbf{3 5 2}$ & $\mathbf{4 6 0 3 1}$ \\
\hline
\end{tabular}


As seen in the table above, most of verbs that can be modified by qualitative adverb is derivative verbs with adjective and noun as its stem. Examples of deadjectival verb are menjijikan disgusting (the stem is jijik disgusted), bersedih being sad (the stem is sedih sad), bersuka cita being happy (the stem is suka cita happy).

\subsection{Verb Type}

Verbs which are found modified by qualitative adverb sangat very in data mostly are state verbs. Of 12 verb types, there are three verbs that are found in data. Verbs that can be modified by qualitative adverb sangat very are categorized in state verbs, state experiential verb, and state benefactive verbs. The verbs are found in form of base verb and affixed verb, but the amount of affixed verb is much more than base verb.

\subsubsection{State Verb}

According to [11], this verb type only requires Os as its semantic case role. The object noun specifies the entity is in a certain state or condition. categorizes adjective as state verb because in his research adjective and verb is considered as same category. His approach is different with this research which is distinguish adjective and verb as two different categories. All state verbs found in this research is derivative verbs with adjective and noun as the stem.

(6) Mereka yang tampil di layar tiga bulan sesudahnya memang sangat berbeda. (doc\#103

\section{$\mathbf{O}$}

$\mathbf{V}$

[lit.] They who appear on screen three months after indeed very different They who appear on screen after three months are indeed very different.

\subsubsection{State Experiential Verb}

State experiential verbs are found in data in form of base verb and affixed verb. State experiential verbs which are modified by sangat very are exemplified in the following sentences.

(7) Sebenarnya dulu Mbak Mita sangat suka bulu tangkis. (doc\#434)

\section{E $\quad \mathbf{O} \quad \mathbf{O}$}

[lit.] Actually before sister Mita very like badminton Actually Mita used to like badminton before

(8) Orang kaya sangat paham dengan pameo.. (doc\#15346)

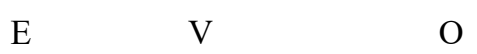

[lit.] People rich very understand with pameo Rich people really understand about pameo

(9) Ia sangat terpesona oleh suara kecapi Hermes (doc\#13298)

$$
\text { E V }
$$

[lit.] He veryfascinated by voice harp Hermes He is very fascinated by Hermes' harp voice

As stated by [11], state experiential verb requires experiencer and object in its semantics. The object sometimes is preceded by a preposition. In example (8), pameo is the object and it is preceded by preposition tentang about . State experiential verbs refers to cognition and emotion as experiencer of state experiential verb is the one who is in psychological state of 
cognition, emotion, or sensation. As seen in data, state experiential verb is not only found as base verb. Verb with prefix ter- can be considered as state experiential verb, e.g. terpesona touched, termotivasi motivated, and terinspirasi inspired. In example (9), ia he/she is the one who experienced psychological state of sensation and the object Hermes' harp voice is precedeed by preposition oleh $b y$.

\subsubsection{State Benefactive Verb}

This verb requires benefactive and object in its semantics structure. Benefactive noun specifies the one who possesses the object or thing and the object noun specifies the object or thing possessed [11]. State benefactive verb is not found in form of base verb in data. All state benefactive verbs found in data is affixed verb. This verb type is found in form of denominal verb which is formed by prefixation process with ber- . Prefix ber- here has grammatical meaning 'mempunyai' as affixed verb with ber- can be respectively paraphrased as 'mempunyai have noun'.

(10) Tindakan ini tentu saja sangat beresiko. (Doc\#7088)

$$
\begin{gathered}
\mathbf{B} \\
\text { [lit.] Action this of course very risky } \\
\text { Of course this action is very risky }
\end{gathered}
$$

Beresiko risky in example (9) above has meaning 'mempunyai resiko (contain risk)' so the sentence can be paraphrased as

(11) Tindakan ini tentu sangat mempunyai resiko

$$
\text { This action of course really has risk. }
$$

Base of the affixed verb is representing object in its semantic structure so the verb is counted as state benefactive verb. There is also memiliki as state benefactive verb found in data as in the following example.

(12) Menurut saya mereka sangat memilki integritas secara global. (doc\#5414)

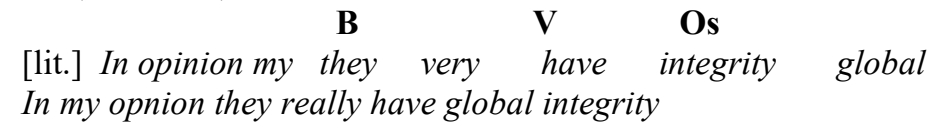

Qualitative verb gives meaning to scalar change as well. As stated before, this adverb is also called as degree adverb which shows scalar change and the verb that can be modified by this adverb is also called as degree verb. Adjective as the stem of derived verbs lexicalize scara attributes to the verb. Thus, the verb is able to be modified by qualitative adverb. This corresponds to Levin's research [12] which find that scalar change verb typically are deadjectival. In contrast to an adjective, scalar change verb tends to be stative. That is also found in this research that verb type which can be modified by qualitative adverb is state verb as explained below. Derived verbs may give impact that causes the verbs can accept modification with qualitative adverb. It is because most of derived verbs found here are deadjectival verb. Adjective as stem influences the affixed verb to accept modification with qualitative adverb as adjective is prototypical category which can be modified by qualitative adverb. State experiential verb is also found as verb which accepts modification with qualitative adverb. Fleischhauer [13] states that experiencer verb is probably the prototypical instances of gradable verb. Experiencer verbs here also refer to Levin's psych verb. Experiencer verbs found here are not limited to emotion verb which is experienced by the experiencer, but also cognitive verb [14]. 


\section{Conclusion}

Most of verbs that can be modified by qualitative adverb are affixed verbs. There are only thirteen base verbs found being modified by qualitative adverb. Verbs type which accept modification with qualitative adverb sangat very is state verbs. There are three types of state verbs that can be modified by qualitative adverb, that are state verb, experiential verb, and benefactive verb. Action and process verbs are not found in data which means these two verb types do not accept modification with qualitative adverb sangat. As most of verbs are affixed verbs, the stem of verbs give influence that causes the verb can accept modification by qualitative adverb. This study only focuses on verb type that can be modified by qualitative adverb so that another study can be conducted to have in-depth explanation of this case by investigating the stem. By investigating the type of the stem, we will have deeper explanation of why those verb accept modification of qualitative adverb.

\section{Acknowledgement}

This research was supported by Universitas Indonesia. We are also immensely grateful to the reviewers for their comments on an earlier version of the manuscript, although any errors are our own and should not tarnish the reputations of these esteemed professionals.

\section{References}

[1] H. Alwi, S. Dardjowidjojo, H. Lapoliwa, and A. M. Moeliono, Tata Bahasa Baku Bahasa Indonesia (Indonesian Grammar), Ketiga. Jakarta: Balai Pustaka, 2003.

[2] C. Stoffel, Intensives and down-toners: a study in English adverbs. Heidelberg: C. Winter's University Buchhandlung, 2007.

[3] D. Bolinger, "9. INTENSIFIERA WITH VERBS," in Degree Words, DE GRUYTER, 2013.

[4] R. Huddleston, R. Quirk, S. Greenbaum, G. Leech, and J. Svartvik, A Comprehensive Grammar of the English Language. London: Longman, 1985.

[5] H. Kridalaksana, Kelas kata dalam bahasa Indonesia. Jakarta: PT Gramedia Utama, 2007.

[6] R. Jackendoff, X' syntax: A study of phrase structure. 1977.

[7] J. Doetjes, A. Neeleman, and H. Van de Koot, "Degree Expressions," Linguist. Rev., vol. 21, pp. 1-66, Jan. 2004.

[8] J. N. Sneddon, A. Adelaar, D. N. Djenar, and M. C. Ewing, Indonesian reference grammar 2nd edition. Sydney: Allen \& Unwin, 2010.

[9] A. N. Sofyan, "Eksistensi Verba dalam Kajian Bahasa Indonesia," Metahumaniora, vol. 8, no. 2, pp. 193-204, 2018.

[10] K. Precht, D. Biber, S. Conrad, and R. Reppen, Corpus Linguistics: Investigating Language Structure and Use. Cambridge: Cambridge University Press, 1998.

[11] D. P. Tampubolon, Verbal affixations in Indonesian: a semantic exploration, vol. 48. Canberra, A.C.T., Australia: Dept. of Linguistics, Research School of Pacific Studies, Australian Natl. Univ., 1983.

[12] B. Levin and M. Hovav, "Lexicalized scales and verbs of scalar change," 46th Annu. Meet. Chicago Linguist. ..., pp. 1-17, 2010.

[13] J. Fleischhauer, Degree Gradation of Verbs. Dusseldorf: Dusseldorf University Press, 2016.

[14] K. Saddhono, "Language and superdiversity: Indonesians knowledging at home and abroad. By Zane Goebel." Soc. Stu. vol. 12 no.1 pp. 113-118, 2018 